\title{
COMPARISON OF UDMURT, ESTONIAN, AND FINNISH DIALOGUES: CHARACTERISTICS OF COMMUNICATIVE BEHAVIOUR
}

\author{
Elena Ryabina \\ Tallinn University and the Institute of the Estonian Language, Tallinn
}

\begin{abstract}
This study aimed at locating Udmurt culture in the continuum of high- and lowcontext cultures using the parameter of time-patterning to analyse radio dialogues. The results were compared with the findings of research on the communicative behaviour of Estonians and Finns (Pajupuu, 1995a). In theoretical works on inter-cultural communication low-context communication compared to high-context communication is claimed to show no long pauses, a higher speech tempo and frequent interruptions of interlocutors. Characteristics of Estonian and Finnish dialogues allow referring Estonian culture to lowcontext and Finnish - to high-context cultures. Udmurt culture with respect to the low rate of interruptions of interlocutors found in the study could be referred to high-context cultures; however, the dialogues displayed very short pauses. Analysis of other types of dialogue, in addition to radio dialogues, is necessary to obtain more data on the communicative behaviour of Udmurts.
\end{abstract}

DOI: $10.3176 /$ tr.2008.1.03

Keywords: communicative behaviour, high- and low-context cultures, dialogue, the turn, pause, simultaneous speaking

\section{Introduction}

Comparative studies of Finno-Ugric languages have been extensive over time. As to research into the features of communicative behaviour among Finno-Ugric peoples, there have been few studies that focused on the comparative aspect of the question (for example, Pajupuu 1995a, 1995b, 1997; Ryabina 2007). It has been ascertained that correlation between language and communicative behaviour is considerably weaker than that between culture and communication (Pajupuu 1995a, 1995b; Wierzbicka 1998).

This article compares the communicative behaviour of Udmurts, Estonians and Finns. Communicative behaviour is defined here as a set of such norms and 
standards of discourse, or dialogue, as the length of a turn, the duration of a pause and the strategy of taking turns. The analysis reported in the article aimed at defining the location of Udmurt culture in the continuum of high- and low-context cultures with respect to the characteristics of dialogues and at comparing the results with the findings of a study on the communicative behaviour of Finns and Estonians.

\subsection{The concept of low- and high-context cultures}

E. T. Hall (1976) distinguishes between two categories of culture with respect to the quantity of information conveyed by a message. In some of the cultures information is explicit, it is largely verbalized. These are defined by E. T. Hall as low-context cultures. In other cultures, utterances cannot be understood solely on the basis of the language-related signs. They can be adequately interpreted only if the context is known. Such cultures are defined as high-context cultures (Hall 1976:91).

The main purpose of low-context communication is to convey information. The speaker is responsible for imparting the message clearly so that the interlocutor could easily decode it (Ting-Toomey 1999:101, 209). Communication in high-context cultures is an emotional involvement rather than a mere transfer of information (Pajupuu 1995a). In high-context cultures it is the listener who is responsible for the adequate interpretation of the message (Ting-Tomey 1999:101, 209); the speaker imparts information not only verbally, but also using gestures, intonation and even silence (Ting-Toomey 1999:100; Samovar and Porter 2004:76).

The concept of high- and low-context communication is associated with the theory of individualistic-collectivistic cultures (Gudykunst and Ting-Toomey 1988; Hofstede 2001). Individualistic cultures (for example, Switzerland, Germany, United States, Scandinavian countries) are referred to low-context cultures; collectivistic cultures (Asian countries - Japan, China, Korea; American Indians, Arabic and other countries) are referred to high-context cultures (Hall 1976; Gudykunst and TingToomey 1988; Samovar and Porter 2004:77).

In individualistic low-context cultures private life is separated from the other life spheres, thus the interlocutors do not know much about each other and for communication they need detailed information (Hall 1976, Hall and Hall 1990:6-7). In collectivistic high-context cultures people are involved in close relationships with family members, friends, colleagues; they have extensive information about the life of people around them and therefore do not impart detailed information (Hall 1976, Hall and Hall 1990:6-7).

\subsection{Dialogues as a parameter in inter-cultural communication studies}

Many researchers of inter-cultural communication argue that differences between low- and high-context cultures are displayed in dialogues. In low-context cultures conversation is fast, without long pauses, and the interlocutor is frequently interrupted (Hall, 1983:63; Halmari 1993; Shigemitsu 2005). In high-context cultures (for example, those of American Indians, Chinese and Japanese) dialogue consists of 
long turns alternating with longer pauses and quiet listening; interruptions are rare. The Japanese can have up to 5 seconds long and American Indians of Navajos - up to 10 seconds long pauses (Clark 1998, Shigemitsu 2005).

Y. Shigemitsu (2005) has studied the duration of pauses in dialogues between Americans (low-context culture), Japanese (high-context culture) and Chinese (highcontext culture). The study has shown that there were fewer pauses in the dialogue between the Americans. In dialogues between the Japanese and the Americans pauses were always interrupted by Americans and longer turns were also taken by Americans, as the Japanese failed to take the turn amidst the highly fluent speech of the Americans. The Japanese found it easier to participate in a dialogue with the Chinese, since there are similarities in the communicative behaviour of the Japanese and the Chinese - for example, a similar attitude towards silence. In the American tradition of communication pause is not acceptable in a dialogue, it is a violation of the norm of discourse, while for the Japanese and the Chinese pause is a norm and a means of communication. During a pause interlocutors can be engaged in interpreting the message, preparing an answer and a new theme (Shigemitsu 2005).

\subsection{Communicative behaviour of Estonians and Finns}

The analysis of literature shows that every culture has characteristic features of communication. In this respect, it is interesting to research the communicative behaviour of peoples from the same language group. In this work, the communicative behaviour of Estonians and Finns studied by comparing data from the analysis of radio dialogues (Pajupuu 1995a, 1995b) will be treated. The analysis has shown that Finns take twice longer turns as Estonians, pauses in the Finnish dialogues are also longer. The Finns quietly listen to each other, interruptions of the interlocutor are rare. The Estonians frequently interrupt the interlocutor promptly taking turns. Besides, Estonian speech is considerably faster than Finnish speech: Estonians utter 158 words per minute, Finns - 114 words per minute. According to H. Pajupuu, Finnish culture can be referred to the high-context category, while Estonian culture - to the low-context category of cultures (Pajupuu 1995a, 1995b: 768-769).

Another study based on telephone calls between Finnish (high-context culture) and American (low-context culture) businessmen (Halmari 1993) also showed that Americans interrupted their Finnish interlocutor three times more frequently than Finns did while speaking with an American interlocutor. Finnish businessmen very rarely interrupted their interlocutor; in the majority of cases they uttered interjections to signal understanding and the interlocutors' last words or even last syllables of words were uttered simultaneously. As to the rate of speech the Americans spoke faster than the Finns.

Both Finland and Estonia are referred to individualistic countries by G. Hofstede (2001:215, 502). According to W. B. Gudykunst and S. Ting-Toomey (1988), in individualistic cultures low-context communication is dominant. The question arises why communication in Finnish culture tends to be high-context although Finland is an individualistic country. The answer might be: it is an exception to the rule. 
Finnish communicative behaviour compared to that of other Europeans is specific (Koessegi et al. 2004); it has features of communicative behaviour characteristic of the Asian communicative type - for example, the attitude to silence (Lehtonen and Sajavaara 1985). J. Lehtonen and K. Sajavaara (1985) find that a typical Finn is a silent listener; in Finnish culture it is considered impolite to interrupt the interlocutor.

Estonian and Finnish cultures have a different background. Estonian culture has been influenced by several cultures, including Danish, Swedish, German, Russian. Estonia was also incorporated into the Soviet Union. Finnish culture has mainly been influenced by Swedish culture, although Finland was once also a Russian province. It can be suggested that the Finno-Ugric type of culture has been preserved more in Finnish than Estonian culture, because Finland has been less influenced by other cultures.

\subsection{The background of Udmurt culture}

The communicative behaviour of Udmurts has been studied by E. Ryabina (2007). It has to be mentioned that Udmurts are the native people of the Udmurt Republic, which is part of the Russian Federation. Udmurtia is in the Western part of the Urals, on the border between Europe and Asia. This territory has long been a place where active contacts between Finno-Ugric, Slavic and Turkic peoples evolved.

As it has been mentioned above, each nation has specific features of communicative behaviour. The standards of communication are acquired in the course of socialization, which starts in early childhood and continues in the kindergarten, school, university, at working place. G. Hofstede argues that if a state is not homogeneous (there are regional, ethnic, religious differences), the process of socialization takes place on several levels (Hofstede, 1991:4, 10). Socialization among Udmurts is maintained both within the ethnic community and within the Russian Federation. G. Hofstede (Hofstede, 2001:502) refers Russia to collectivistic countries. Research on the communicative behaviour of Russians has not been abundant. Turunen has mentioned that Russians are talkative, they express their opinion and want to be listened to, they like to impress others and demonstrate their capacity to cope with any question. Russians tend to be dominant in a conversation; they take long turns so that the interlocutor, especially one from a different culture, can hardly utter a single word. As listeners, Russians are active - they signal comprehension by uttering interjections, using mimics and gestures (Turunen 2000).

\subsection{Communicative behaviour of Udmurts: preliminary hypothesis}

The hypothesis to be tested in our study was as follows. The Udmurt culture is more high-context than Finnish individualistic culture, which has had an impact of the Swedish individualistic low-context culture. Udmurt culture has been influenced by Russian and Tatar collectivistic cultures. There are also language- 
specific features that could be considered relevant for defining Udmurt culture as one having higher contextuality than, for example, Finnish.

Firstly, it has been claimed that in high-context cultures a difference is made between the 'insiders' and 'outsiders' (Hall 1976). In Udmurt, the first person plural form is conveyed by two pronouns: $m i$ and as'meos. $M i$ is used in cases when the interlocutor is an 'outsider', and as'meos - when the interlocutor is an 'insider'. For example, a schoolboy talking with his mother refers to his mates and him using the pronoun mi. In a talk with one of his mates he would use as'meos.

Secondly, in high-context cultures the social status of a person - age, sex, social position - are taken into consideration (Hall 1976; Gudykunst and TingToomey 1988). In Udmurt there is an abundance of kinship terminology. For example, words with the root $t c ̌ u z$ are used for naming the relatives of the mother: tčužaj 'grandmother', tčužataj 'grandfather', tčužmurt 'uncle', tčužapaj 'aunt', while pesjanaj 'grandmother', pesjataj 'grandfather', agaj 'uncle', apaj 'aunt' are used for the relatives of the father. An older relative's wife is kenak, a younger one's - ken. An older relative's husband is kyrs' $i$ and a younger relative's husband is èmespi. Elder brother is called agaj, younger brother - vyn; elder sister - apaj, younger sister - suzèr. An older person is not called by name. Even today, calling elder brothers and sisters by name in some families is not customary.

Thirdly, in high-context cultures intonation is used to convey information (Ting-Toomey 1999:100). In Udmurt the word tauna 'please' is used only in response to the interlocutor's expression of gratitude, while polite request is conveyed by intonation.

Further, rural inhabitants do not greet a person by saying, for example, 'Good morning/evening'; they would ask instead: 'Where are you going to?' This might sound impolite for people from other cultures, but for Udmurts it is quite normal: small talk is implicitly also a greeting. Thus, the context carries an implication.

\section{Case study: communicative behaviour of Udmurts}

In the study of the communicative behaviour of Udmurts excerpts from 10 dialogues between prominent figures of the Udmurt community (journalists, politicians, scientists, writers, etc) were analysed. The dialogues were recorded in 2005 by the Mynam Udmurtie radio broadcasting programme Mi doryn kunoyn as direct transmission.

\section{1. Methods}

The analysis focused on the duration of utterances and pauses as well as on the strategy of turn taking in the aforementioned dialogues. To measure the duration of turns, pauses and the interlocutors' simultaneous speaking the computer programme Sound Forge 8.0 was used.

Symbols for the dialogue components were as follows (Pajupuu, 1995): 
a - the turn of the leading interviewer without intra-turn double speaking $((s) a b)$ and intra-turn pauses $((s) p)$,

$\boldsymbol{b}$ - the turn of the interviewee without intra-turn double-speaking $((s) \boldsymbol{a b})$ and intra-turn pauses $((s) p)$,

$(s) a b$ - simultaneous speaking not leading to turn-switching (intra-turn double speaking),

(l) $\boldsymbol{a b}$ - simultaneous speaking leading to a switching of turns (turn-ending double speaking)

(s)p - pause not leading to turn-switching (intra-turn pause).

In the analysis, silence exceeding $200 \mathrm{~ms}$ was accepted as a pause occurring in an utterance.

Note. Measurements were made only of pauses preceded by falling intonation; a tone fall implies soliciting a turn switching.

(l)p - pause leading to a switching of turn (turn-switching pause).

Firstly, the duration of all the dialogue components were measured; subsequently, the percent of the duration of a dialogue component in relation to the duration of the whole dialogue, the average duration (in seconds), standard deviation, and the number of occurrences of each component were found. The measurement results are shown in Table 1.

In addition to the analysis of data on the components of dialogue, average speech rate in the dialogues was measured. To do this, the number of words uttered within the first minute of dialogue was counted. The rate of speech in Udmurt dialogues was compared to that in Estonian and Finnish dialogues.

For the comparison of Udmurt dialogues with Estonian and Finnish dialogues the results of an analogous study of Estonian and Finnish radio dialogues between prominent society members (Pajupuu 1995a) were used. Mean durations of the components of Udmurt, Estonian and Finnish dialogues are shown in Table 2.

Table 3 shows the ratio between mean durations of the components in the Udmurt and in the Estonian and Finnish dialogues. Average durations of the components in the Udmurt, Estonian and Finnish dialogues are shown in Figure 1.

Table 1. General characteristics of the Udmurt dialogue components

\begin{tabular}{l|c|c|c|c|c}
\hline $\begin{array}{c}\text { Dialogue } \\
\text { components }\end{array}$ & $\begin{array}{c}\text { total duration } \\
(\mathrm{sec})\end{array}$ & $\begin{array}{c}\text { \% of the total } \\
\text { dialogue } \\
\text { duration }\end{array}$ & $\begin{array}{c}\text { mean } \\
\text { duration } \\
(\mathrm{sec})\end{array}$ & $\begin{array}{c}\text { frequency of } \\
\text { occurrence }\end{array}$ & $\begin{array}{c}\text { \% of all } \\
\text { component } \\
\text { occurrences in } \\
\text { the dialogue }\end{array}$ \\
\hline $\mathrm{a}$ & 759.872 & 21.7 & 9.16 & 7.72 & 83 \\
$\mathrm{~b}$ & 2627.716 & 75.2 & 17.29 & 18.59 & 152 \\
(s)ab & 8.537 & 0.2 & 0.85 & 0.89 & 10 \\
(l)ab & 9.58 & 0.3 & 0.80 & 1.12 & 12 \\
(s)p & 53.44 & 1.5 & 0.53 & 0.31 & 100 \\
(l)p & 28.755 & 0.8 & 0.56 & 0.35 & 51 \\
Total & 3495.9 & 100.0 & & 7.72 & 83 \\
\hline
\end{tabular}


Table 2. Average component durations in the Udmurt, Estonian and Finnish dialogues

\begin{tabular}{l|c|c|c}
\hline Dialogue components & Est mean (sec) & Fin mean (sec) & Udm mean (sec) \\
\hline a & 9.16 & 6.13 & 11.66 \\
$\mathrm{~b}$ & 17.29 & 9.55 & 21.92 \\
(s)ab & 0.85 & 1.16 & 0.82 \\
(l)ab & 0.80 & 1.60 & 1.44 \\
(s)p & 0.53 & 0.99 & 1.25 \\
$(\mathrm{l}) \mathrm{p}$ & 0.56 & 0.87 & 1.02 \\
\hline
\end{tabular}

Table 3. Ratios between mean durations of dialogue components in the Udmurt, Estonian and Finnish dialogues

\begin{tabular}{c|c|c|c}
\hline Dialogue components & Fin mean/ Est mean & Udm mean/ Fin mean & Udm mean/ Est mean \\
\hline $\mathrm{a}$ & 1.9 & 0.8 & 1.5 \\
$\mathrm{~b}$ & 2.3 & 0.8 & 1.8 \\
(s)ab & 0.7 & 1 & 0.7 \\
(l)ab & 0.9 & 0.5 & 0.5 \\
(s)p & 1.3 & 0.4 & 0.5 \\
(l)p & 1.2 & 0.5 & 0.6 \\
\hline
\end{tabular}

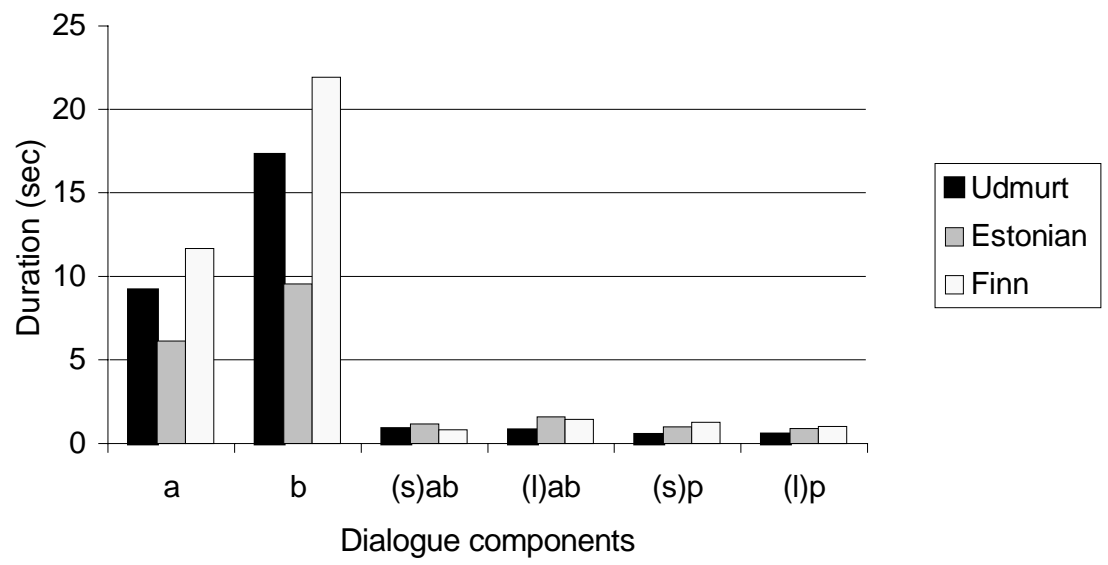

Figure 1. The mean duration of the Udmurt-Udmurt, Estonian-Estonian and the Finn-Finn dialogue components.

\section{Results}

Table 1 shows the characteristics of components in the Udmurt-Udmurt dialogues.

As seen from the table, the duration of the interviewer's turns was $21.7 \%$, the duration of the interviewee's turns $-75.2 \%$ of the total dialogue duration. The 
percent of intra-turn simultaneous speaking was very low $-0.2 \%$ of the total duration of the dialogue; it occurred 10 times. It should be noted that in 8 cases the interlocutor signalled comprehension by uttering interjections (for example, $m-m$ ). In 2 cases the interlocutors' words were concurrent.

The percent of simultaneous speaking in the end of a turn was also low $-0.3 \%$ of the total duration of a dialogue, or 12 occurrences. In 6 cases, last syllables of words were concurrent, in 1 case - the last word, in 2 cases the interviewer prompted a suitable word to the interviewee, and in 3 cases several words were concurrently uttered.

Intra- and inter-turn pauses were not long: $0.53 \mathrm{sec}$. and $0.56 \mathrm{sec}$. respectively. The longest intra-turn pause lasted $2.2 \mathrm{sec}$. and the inter-turn pause $-1.6 \mathrm{sec}$.

Table 2 shows the mean durations of dialogue components in the Udmurt, Estonian and Finnish dialogues. Table 3 shows the ratio between the mean duration of dialogue components in the Finnish and Estonian, Udmurt and Finnish, and Udmurt and Estonian dialogues.

The mean duration of each of the dialogue components in the Udmurt, Estonian and Finnish dialogues is shown in Figure 1.

Table 3 and Figure 1 show that turns in the Udmurt dialogues were shorter than in the Finnish and longer than in the Estonian dialogues $(a, b)$. Turns in the Estonian dialogues were twice as short as in the Finnish dialogues (a, b).

Udmurts and Finns rarely interrupted the interlocutor in intra-turn utterances ((s)ab), Estonians spoke simultaneously ((s)ab, (l)ab) longer than Finns and Udmurts. In the end of a turn, Udmurts had the lowest occurrences of simultaneous speaking (l)ab).

Pauses in the Udmurt dialogues were 2 times shorter than in the Estonian and Finnish dialogues ((s)p, ((l)p).

Speech rate measured in the dialogues was 128 words per minute in the Udmurt dialogues, 158 words per minute in the Estonian and 114 words per minute in the Finnish ones.

\section{Discussion and conclusions}

In this article, the characteristics of Udmurt dialogues have been compared to those of Estonian and Finnish dialogues in order to define the type of communicative behaviour of Udmurts with respect to the Estonian and Finnish communicative behaviour and to locate Udmurt culture in the continuum of highand low-context cultures.

The findings of analysis are as follows. Turns were found to be the longest in Finnish dialogues. Turns in Udmurt dialogues were longer than in Estonian and shorter than in Finnish dialogues, turns in Estonian being twice as short as in Finnish. Pauses in Finnish and Estonian dialogues were nearly twice as long as in Udmurt dialogues. The duration of pauses in Finnish dialogues slightly exceeded that in Estonian dialogues. The speech rate of the Udmurts was higher than that of 
the Finns but lower than that of the Estonians. The interlocutor was interrupted the most frequently in Estonian dialogues; the Udmurts had the lowest occurrence of interruptions. Finns rarely interrupted the interlocutor, too.

Thus, characteristic features of Finnish dialogues are quiet speech, long turns, long pauses and silent listening to the interlocutor. Estonian dialogues showed high speech rate, frequent turn-switching and relatively frequent interruption of the interlocutor. Udmurt dialogues displayed moderate speech rate and silent listening to the interlocutor. The aforementioned features can be considered to be characteristic of the Udmurt, Estonian and Finnish communicative behaviour.

It has been maintained in the research of inter-cultural communication that the shorter the pauses in dialogues the higher the speech rate; the interlocutor is more frequently interrupted. This was not observed in Udmurt dialogues. Pauses in Udmurt dialogues were very short; intra-turn pauses were $0.53 \mathrm{sec}$. long and interturn pauses $-0.56 \mathrm{sec}$. The longest intra-turn and inter-turn pauses lasted $2.2 \mathrm{sec}$. and $1.6 \mathrm{sec}$., respectively. According to the results of research by Y. Shigemitsu (2005) and D. C. Clark (1998), pauses in Japanese dialogues can last as long as 5 sec. and in the dialogues of Indians - even $10 \mathrm{sec}$. It should be taken into account, though, that the Udmurt dialogues were recorded in a direct radio programme, during which long pauses are broken. It could also be suggested that short pauses in the Udmurt dialogues are associated with Russian communicative behaviour. In the Russian dialogue pause implies hesitation, lack of confidence (Turunen 2000).

The results obtained from this study of the communicative behaviour of Udmurts are similar to the findings of a study by H. Halmari (1993), in which telephone calls between Finns and Americans were analysed. Finns rarely interrupted the interlocutor; they uttered interjections to show understanding and the interlocutors simultaneously uttered only last syllables of words.

The current study therefore concludes that the Udmurts and the Finns are silent listeners. However, the Udmurts are silent only during the interlocutor's turn. As soon as the turn is over they start speaking and keep speaking relatively long without making long pauses. Speech rate in the Udmurt dialogue is thus higher than in the Finnish dialogue. The communicative behaviour of Estonians differs from both the Udmurt and Finnish type of behaviour.

On the basis of the temporal characteristics of dialogues Udmurt culture could be referred to the category of high-context cultures taking into consideration the low occurrence of interruptions in the Udmurt dialogues. On the other hand, turns in Udmurt dialogues are shorter than in Finnish dialogues; pauses are shorter than in both Finnish and Estonian ones. Hence, the assumption that Udmurt culture could be referred to cultures with higher contextuality than Finnish is not confirmed.

In this study, the temporal characteristics of Udmurt radio dialogues were analysed against the background of the results of research on Finnish and Estonian radio dialogues. To obtain more data on the communicative behaviour of Udmurts, it is necessary to analyse several types of material, in addition to radio dialogues. 


\section{Acknowledgements}

This article is based on the author's Master of Arts dissertation "Temporal characteristics in Udmurt dialogues" (Ryabina 2007). The author expresses gratitude to the supervisor of the work Hille Pajupuu for useful recommendations. The author also thanks Niina Aasmäe for her help in translating the article into English.

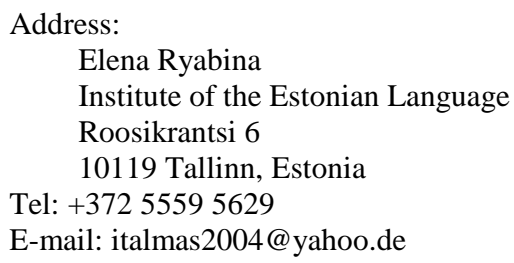

\section{References}

Clark, Diane C. (1998) „Communication between cultures: Navajo discourse strategies in interethnic interactions". In Intercultural Communication Studies (VIII-1), 9. http://www.trinity.edu/org/ ics/ICS\%20Issues/ICS\%20VIII/ICS-VIII-1-Clark.pdf (15.11.2006)

Gudykunst, William B. and Stella Ting-Toomey (1988) Culture and Interpersonal Communication. Newbury Park: Sage.

Hall, Edward T. (1976/1989) Beyond culture. New York: Anchor Books.

Hall, Edward T. (1983/1989) The dance of life. The other dimension of time. New York: Doubleday.

Hall, Edward T. and Mildred R. Hall (1990) Understanding cultural differences: Germans, French, and Americans. Yarmouth/Main: Intercultural Press.

Halmari, Helena (1993) „Intercultural business telephone conversations: a case of Finns vs. AngloAmericans". Applied Linguistics 14, 4, 408-430.

Hofstede, Geert (2001) Culture's consequences: comparing values, behaviors, institutions, and organizations across nations. 2nd ed. Thousand Oaks: Sage.

Hofstede, Geert (1991/1997) Cultures and organizations. Software of the mind. London: McGrawHill.

Koeszegi, Sabine, Rudolf Vetschera, and Gregory Kersten (2004) „National cultural differences in the use and perception of internet-based NSS: Does high or low context matter?" International Negotiation 9, 79-109.

Lehtonen, Jaakko and Kari Sajavaara (1985) „The silent Finn”. In Perspectives on Silence, 193-201. Deborah Tannen and Muriel Saville-Troike, eds. Norwood, NJ: Ablex Publ.Corp.

Pajupuu, Hille (1995a) „Cultural context, dialogue, time”. Estonian Academy of Sciences. Institute of the Estonian Language. Preprint. Tallinn. http://www.eki.ee/teemad/kultuur/context/ context.html (20.02.2006)

Pajupuu, Hille (1995b) „Eestlaste ja soomlaste kommunikatsioonikäitumise tagamaadest”. [Background of the communicative behaviour of Estonians and Finns] Keel ja Kirjandus (Tallinn) $11,767-776$.

Pajupuu, Hille (1997) „Eestlased ja soomlased - probleemitud suhtlejad”. [Estonians and Finns problem-free communicators] Keel ja Kirjandus (Tallinn) 8, 547-550. http://www.eki.ee/ teemad/kultuur/estfin/estfin.html (15.05.2006) 
Ryabina, Elena (2007) „Udmurdi vestluskäitumise põhijooni dialoogi ajalise ülesehituse põhjal”. [Temporal characteristics of the Udmurt dialogue.] M.A Theses. University of Tallinn, Tallinn.

Samovar, Larry A. and Richard E. Porter (2004) Communication between cultures. 5th ed. Wadsworth: Thomson Learning.

Shigemitsu, Yuka (2005) "Different interpretations of pauses in natural conversation - Japanese, Chinese and Americans". Presented in the panel titled 'Discoursal Problems in CrossCultural Conversations (Organizer: Motoko Hori) in 9th International Pragmatics Conference, Riva del Garda, Italy, 10-15 July 2005. http://www.t-kougei.ac.jp/engineering/ kiyou/2005/02-02.pdf (8.12.2006)

Ting-Toomey, Stella (1999/2002) Communicating across cultures. London: The Guilford Press.

Wierzbicka, Anna (1998) "German 'cultural scripts': public signs as a key to social attitudes and cultural values". Discourse \& Society 9, 2, 241-282.

Turunen, Natalia (2000) „Russkij harakter i kommunikativnoe povedenie v vosprijatii finnov”. [Finnish perception of Russian character and communicative behaviour] In Russkoe $i$ finnskoe kommunikativnoe povedenie 1. [Russian and Finnish Communicative Behaviour 1.] Sterenin, Iosif A., ed. Voronež: VGTU. http://commbehavior.narod.ru/RusFin/RusFin2000/ IntroWCB.htm (15.09.2006) 